\title{
STRATEGI KOMUNIKASI PEMASARAN LASAGNA LARISE DALAM MENINGKATKAN PENJUALAN
}

\author{
Irodatul Khasanah \\ Universitas Islam Negeri Sunan Ampel Surabaya \\ Irodatulkhasanah@gmail.com
}

\section{Article Info}

\section{Article history:}

Received 10 Februari 2019

Accepted 13 Maret 2019

Published 10 April 2019

\section{Keyword:}

Komunikasi, Pemasaran,

Bauran Pemasaran,

Strategi Pemasaran,

Lasagna Larise

\section{Abstract}

This article discusses how Lasagna Larise's strategy is to increase its sales. This study uses a qualitative-descriptive approach to describe facts and data. The result of this research is Lasagna Larise puts forward appropriate products, quality, and prices, uses vigorous promotions and locations that attract buyers. In addition, they also use advertising and education independently for prospective buyers, especially for resellers who will later resell their products and of course purchase more than retailers. The benefits provided are also attractive to potential buyers. Further education is still being carried out to increase the number of sales and customer loyalty.

Artikel ini membahas tentang bagaimana strategi yang dilakukan Lasagna Larise untuk meningkatkan penjualannya. Penelitian ini menggunakan pendekatan kualitatif-deskriptif untuk mendeskripsikan fakta dan data. Hasil penelitian ini adalah Lasagna Larise mengedepankan produk, kualitas, dan harga yang sesuai, menggunakan promosi yang gencar dan lokasi yang menarik minat pembeli. Selain itu, mereka juga menggunakan iklan dan edukasi secara mandiri pada calon pembeli, khususnya untuk reseller yang nantinya akan menjual kembali produk mereka dan pembeliannya tentu lebih banyak daripada para pengecer. Benefit yang diberikan juga menjadi pemikat tersendiri bagi para calon pembeli. Edukasi lanjutan tetap dilakukan untuk meningkatkan jumlah penjualan dan loyalitas pelanggan.

\section{Editorial Office:}

Program Studi Ilmu Komunikasi, Fakultas Dakwah dan Komunikasi, UIN Sunan Ampel Surabaya. Jl. Ahmad Yani 117 Surabaya, Jawa Timur, Indonesia.

Email: jurnalilkom@uinsby.ac.id 


\section{Pendahuluan}

Dewasa ini seperti yang sama sama kita ketahui, industri kuliner sedang naik daun, makanan dan minnuman kekinian sedang di lomba lombakan menunya di berbagai outlet kuliner. Cafe-cafe dan sentra kuliner baru bermunculan dengan menyuguhkan yang terhangat di masyarakat. Mie dengan cita rasa pedas sedang marak maraknya saat ini atau cemilan yang berbau pedas. Media online bisa jadi salaah satu pendukungnya. Instagram yang menyuguhkan visual lebih serta kemudahan akses dan banyaknya fitur tentunya membuat penggunanya betah berlama lama menggunakan aplikasi yang satu ini. Hal ini tentunya berkaitan dengan perkembangan sistem dan strategi pemasaran dari para pemilik bisnis kuliner yang ada.

Strategi pemasaran dalam dunia bisnis jelas memiliki peran yang sangat penting dalam sebuah proses pembentukan kesadaran dan edukasi konsumen. Pemasaran disini adalah sebuah kegiatan yang biasanya dilakukan oleh perusahaan untuk menghadapi persaingan atau mempertahankan kelangsungan dari usaha yang mereka jalankan untuk memperoleh laba sesuai keinginan perusahaan tentunya mereka harus berjuang lebih karena tentunya komunitas kompetitor yang ada di dunia luar pasti akan sangat banyak. Ketika ada sebuah perusahaan yang memulai hal baru tentunya pasti ada perusahaan-perusahaan lain yang akan menciptakan hal yang serupa di mana akan muncul kompetitor kompetitor di bidang yang sama atau bahkan mereka akan melakukan inovasiinovasi yang lebih baik daripada yang telah dilakukan oleh instansi pertama yang meluncurkan sebuah program. Peneliti memutuskn untuk melakukan penelitian di Lasagna Larise karena bagi peneliti itu merupakan hal yang tentunya tidak biasa dan patut untuk diteliti lebih lanjutnya. Brand Lasagna Larise ini merupakan prduk olahan rumahan atau seringnya disebut home industry namun produk Lasagna Larise ini telah mampu dipasarkan ke berbagai kota di Indonesia. Mungkin di era internet yang serba mudah segala-galanya in terdengar tidak istimewa. Namun disini peneliti menelaah lagi bahwasanya produk ini merupakan olahan frozen food. Selain itu produk ini juga bukan jenis makanan lokal dimana ini merupakan makananan olahan pasta yang terkenal khas di negara Italia.

Lasagna Larise sendri telah ada sejak tahun 2017 dan hingga kini masih terus hidup dan berkembang. Dulu awalnya owner dari Lasagna Larise ini memulai usaha berkat resep dari temannya, sebelum hijrah ke Batam, yang kemudian peninggalan berupa resep ini akhirnya yang kini cukup dikenal banyak orang. Awal mulanya yang tahu ini hanya ibuibu pengajian setempat di komunitas. Lalu lambat laun melaui word of mouth mulailah ada pesanan datang satu persatu. Hingga kini mampu melakukan distribusi hingga luar jawa dan kini memiliki outlet di kawasan PTC Surabaya. Tak bisa dipungkiri makanan makanan hits meraja lela dimana mana saat ini.

Namun Lasagna Larise tetap konsisten dengan produk bawaannya, seperti yang 
kita tahu pada umumnya makanan sejenis lasagna tidak dijual di tempat biasa, seringnya kita menemukan produk sejenis lasagna di restoran restoran besar sejenis Pizza Hut. Lasagna larisse tetap bertahan di posisinya. Pemasaran merupakan sebuah proses sosial dimana sebuah tim akan mendapatkan target yang telah mereka tentukan sebelum memulai pemasaran ini melalui beberapa proses dan pertukaran nilai dengan pihak-pihak lain. ${ }^{1}$

Untuk keperluan tersebut pengusaha dapat melakukan tindakan-tindakan yang terdiri dari 4 macam, yaitu tindakan mengenai produk (product), Harga (price), distribusi atau penempatan produk (place) dan promosi (promotion). Dalam konsep 4P tersebut yang berkaitan dengan bidang komunikasi yaitu poin promosi. Bauran promosi merupakan seperangkat alat yang saling melengkapi dan saling mendukung, yang biasa digunakan adalah iklan, hubungan masyarakat, penjualan pribadi, dan promosi penjualan. ${ }^{2}$

\section{Kajian Pustaka}

\section{Strategi pemasaran}

Strategi pemasaran dapat dinyatakan sebagai dasar tindakan yang mengarah pada kegiatan atau usaha pemasaran, dari suatu perusahaan, dalam kondisi persaingan dan lingkungan yang selalu berubah agar dapat mencapai tujuan yang diharapkan.Strategi pemasaran yang direncanakan untuk mencapai perusahaan dengan mengembangkan keunggulan bersaing yang berkesinambungan melalui pasar yang dimasuki dan program pemasaran yang digunakan untuk melayani pasar sasaran tersebut. Beberapa diantaranya adalah sebagai berikut

a. Segmentasi Pasar

Tiap pasar terdiri dari bermacammacam pembeli yang mempunyai kebutuhan dan kebiasaan yang berbeda. Perusahaan tidak mungkin dapat memenuhi kebutuhan semua pembeli. Karena itu, perusahaan harus mengelompokkan pasar yang bersifat heterogen tersebut kedalam satuan-satuan pasar yang bersifat homogen.

b. Market Positioning

Perusahaan tidak mungkin dapat menguasai pasar secara keseluruhan, maka prinsip strategi pemasaran yang kedua adalah memilih pola spesifik pasar perusahaan yang akan memberikan kesempatan maksimum kepada perusahaan untuk mendapatkan kedudukan yang kuat. Dengan kata lain perusahaan harus memilih segmen pasar yang akan menghasilkan penjualan dan laba paling besar.Segmen pasar semacam ini memiliki 4 (empat) karakteristik, yaitu berukuran cukup besar, mempunyai potensi untuk berkembang terus, tidak memiliki atau dipenuhi oleh perusahaan saingan, mempunyai

\footnotetext{
${ }^{1}$ Philip Kotler dan. Gray Amstrong, Dasar-Dasar. Pemasaran. ed. 9, terj.. Alexander Sindoro, (Jakarta: PT Indeks, 2004), 7.
}

2 Indriyono Gitosudarmo, Manajemen Strategis, (Yogyakarta: BPFE-Yogyakarta, 2001), 203. 
kebutuhan yang belum terpenuhi, yang mana kebutuhan tersebut dapat dipuaskan oleh perusahaan yang memilih segmen pasar tersebut.

c. Market Entry Strategy

Market entry Strategy adalah strategi perusahaan untuk memasuki segmen pasar yang dijadikan pasar sasaran penjualan. Strategi memasuki suatu segmen pasar dapat dilakukan dengan cara misalnya membeli perusahaan lain. Cara ini merupakan cara yang paling mudah dan cepat, cara ini ditempuh apabila perusahaan pembeli tidak mengetahui tentang seluk beluk industri dari perusahaan yang dibeli. Sangat menguntungkan untuk secepat mungkin memasuki segmen pasar yang dikuasai perusahaan yang dibeli. Perusahaan menghadapi macam-macam penghalang untuk memasuki segmen pasar yang bersangkutan melalui internal development, misalnya patent, economies of scale, saluran distribusi yang sulit dimasuki, biaya iklan yang mahal atau kesulitan bahan mentah. Ada perusahaan-perusahaan yang lebih suka berkembang melalui usaha sendiri yaitu melalui research and development karena berpendirian bahwa hanya dengan cara inilah kepemimpinan dalam industri dapat dicapai. Kerjasama dengan perusahaan lain bisa dilakukan, keuntungan dengan cara ini ialah bahwa resiko yang dipikul bersama, dan masing-masing perusahaan saling melengkapi skill dan resources.

d. Timing Strategy

Penentuan saat yang tepat dalam memasarkan barang merupakan hal yang perlu diperhatikan. Meskipun perusahaan melihat adanya kesempatan baik menetapkan objektif dan menyusun strategy pemasaran, ini tidaklah berarti bahwa perusahaan dapat segera memulai kegiatan pemasaran. Perusahaan harus lebih dahulu melakukan persiapanpersiapan baik dibidang produksi maupun dibidang pemasaran, kemudian perusahan juga harus menentukan saat yang tepat bagi pelemparan barang dan jasa ke pasar.

\section{e. Marketing Mix}

Marketing Mix strategy adalah kumpulan variabel-variabel yang dapat dipergunakan perusahaan untuk memepengaruhi tanggapan konsumen. Variabel-variabel yang dapat mempengaruhi pembeli adalah yang disebut 7P (product, Price, Place, Promotion, Participant, Prosess, dan People Physical evidence). Beriku penjelasan mengenai Marketing Mix 


\section{Komunikasi pemasaran}

Komunikasi sendiri berasal dari bahasa inggris "communication" dan bahasa latin "communicatio" yang berarti sama, sama disini adalah sama makna. $^{3}$ Tujuan dari komunikasi sendiri adalah untuk membuat sebuah pemaknaan yang sama antara komunikator dan komunikan.

Keberhasilan dari sebuah komunikasi tentunya ditandai oleh persamaan persepsi antara komunikan dan komunikator karena komunikasi sendiri dapat diartikan sebagai proses untuk pemaknaan secara bersamaan. Pada proses komunikasi itu sendiri tentunya terdapat persepsi dan cara pandang atau penilaian seseorang terhadap sebuah objek yang dipaparkan oleh komunikator kepada komunikan. Persepsi ini merupakan sebuah bagian penting dari proses pemaknaan suatu objek yang dipaparkan pada sifat-sifat tertentu dalam proses pembangunan resepsi ini tentu dipengaruhi oleh banyak hal diantaranya adalah pengalaman ada juga pendidikan yang nantinya akan mempengaruhi pola pikir seseorang

3 Yoyon Mudjiono, Ilmu Komunikasi, (Surabaya: Jaudar Press,. 2012), 7.

4 Darun Hidayat, Komunikasi Antarpribadi dan. Medianya,. (Yogyakarta: Graha.Ilmu, 2012), $1-2$. dalam memaknai apapun sebelum nantinya mereka akan membuat sebuah persepsi akhir pada sebuah statement. $^{4}$

Dalam komunikasi pemasaran pada flowchart nya tentu juga terdapat pesan dan juga sebuah pencitraan dari produk atau jasa yang diunggulkan dari sebuah perusahaan atau institusi atau instansi kepada para konsumen mereka ataupun relasi mereka. komunikasi pemasaran di sini merupakan sebuah aspek penting dan bisa jadi disebut penentu dalam sebuah keberhasilan suatu pemasaran. Dan dalam kata lain komunikasi pemasaran juga bisa dimaknai sebuah proses untuk menyampaikan pesan kepada khalayak ramai atau konsumen yang mereka targetkan atau sasaran konsumen dari sebuah instansi tentang produk-produk kompetitor yang ada di pasaran. Dan dalam prosesnya komunikasi pemasaran ini juga mewujudkan sebuah jasa atau sebuah produk dalam bauran pemasaran atau marketing mix yang akan saya jabarkan pada penelitian saya kali ini dan di dalam marketing mix ini terdapat sebuah proses iklan juga proses penjualan proses promosi proses hubungan dengan masyarakat dan pemasaran secara langsung. ${ }^{5}$

Komunikasi pemasaran atau marketing comunication adalah aspek

\footnotetext{
${ }^{5}$ Swasta dan Irawan, Manajemen Pemasaran Modern, (Yogyakarta: Liberty, 2003), 37.
} 
penting dalam keseluruhan misi pemasaran serta penentu suksesnya pemasaran. Definisi lain mengenai komunikasi pemasaran komunikasi pemasaran merupakan sebuah proses penyampaian pesan kepada khalayak ramai atau umumnya isinya ditujukan kepada konsumen yang telah ditentukan tentang perbedaan produk di pasaran atau produk-produk dari kompetitor. kegiatan komunikasi pemasaran ini adalah kegiatan yang dilakukan untuk pelaksanaan dari bauran pemasaran atau marketing mix. ${ }^{6}$

Pemasaran merupakan sebuah proses komunikasi yang bertujuan untuk memberikan informasi mengenai produk atau jasa yang berkaitan dengan pemuasan kebutuhan dan keinginan dari khalayak. Pada umumnya istilah pemasaran dapat dimaknai sebagai proses manajerial dan pemuasan keinginan dari konsumen yang nantinya juga akan mempengaruhi kehidupan dari usaha mereka, proses pendistribusian produk atau jasa mereka tentunya tidak lepas dari pemasaran ini. Proses yang di mana terdapat perencanaan produk penyiapan barang pengemasan distribusi sampai proses penjualan dan sampai ke tangan akhir atau user tentunya disiapkan pada proses ini. ${ }^{7}$

${ }^{6}$ Swasta dan Irawan, Manajemen Pemasaran Modern, (Yogyakarta: Liberty, 2003), 37.

\section{Strategi Komunikasi Pemasaran}

Strategi komunikasi pemasaran ini memiliki jangkauan yang cukup luas bagaimana strategi untuk pemasaran adalah strategi dimana cara untuk menghadapi persaingan dari kompetitor strategi untuk memasarkan produk strategi untuk memasang harga strategi untuk tempat penjualan dan bagaimana strategi untuk melakukan promosi. Inti dari strategi pemasaran ini adalah pemasaran direncanakan untuk mencapai tujuan sebuah perusahaan atau mendapatkan target yang telah ditentukan sehingga nantinya instansi terkait dapat menjangkau pasar akan lebih mudah karena sebelumnya sudah mendapatkan strategi yang tepat dalam penerimaan pasar yang ada. Komunikasi pemasaran mampu berbentuk pada suatu ekuitas merk juga penjualan produk, lungkungan pemasaran yang dapat mengubah sangat cepat komunikasi yang mendorong suatu penjualan, namun dengan melalui banyak komunikasi pemasaran melalui sebuah iklan, bukanlah satu-satunya yang yang dapat mendorong penjualan.

\section{Komunikasi Pemasaran Terpadu}

Komunikasi pemasaran terpadu, kajian ini sebenarnya mempunyai fokus pada teknikteknik yang pada umumnya sering di gunakan. Contoh advertising (periklanan), personal selling (penjualan

7 Prayudi, Public Relations Stratejik (Yogyakarta: Komunikasi UPN Press, 2012), 181. 
tatap muka), sales promotions (promosi penjualan), public relations (humas), direct marketing (penjualanlangsung) di sertai persiapan-persiapan yang dilakukan oleh sebuah perusahaan maupun pertimbangan yang digunakan oleh sebuah perusahaan. Banyak perusahaan di negara maju saat ini telah menerapkan imc dengan perspektif yang lebih luas. Para pengelola perusahaan melihat imc sebagai cara untuk mengoordinasikan dan mengelola program komunikasi pemasaran mereka untuk memastikan bahwa mereka memberikan pelanggan suatu pesan yang konsisten mengenai perusahaan dan/ atau merek yang dimiliki. Bagi banyak perusahaan, imc memberikan banyak perbaikan dibandingkan metode tradisional yang memperlakukan berbagai elemen komunikasi dan pemasaran sebagai kegiatan terpisah. ${ }^{8}$

IMC adalah proses pengembangan dan implementasi berbagai bentuk program komunikasi persuasif kepada pelanggan dan calon pelanggan secara berkelanjutan. Tujuan IMC adalah mempengaruhi atau memberikan efek IMC adalah proses pengembangan dan implementasi berbagai bentuk program komunikasi persuasif kepada pelanggan dan calon pelanggan secara berkelanjutan. Tujuan IMC adalah mempengaruhi atau memberikan efek

\section{IMC (Integrated Marketing} Communication) adalah sebuah konsep dari perencanaan komunikasi pemasaran yang memperkenalkan nilai tambah dari

\footnotetext{
${ }^{8}$ Morrisan, Periklanan: Komunikasi Pemasaran Terpadu, (Jakarta: Kencana, 2012), 7.

${ }^{9}$ Morissan, Periklanan komunikasi pemasaran terpadu, (Jakarta: Kencana Pranada Mediya Group. 2010), 12.
}

rencana komperhensif yang mengevaluasi peran strategi dari berbagai disiplin komunikasi. ikan Misalnya, periklanan umum, respon langsung, sales promotion, dan PR (Public Relation) mengombinasikan disiplin-disiplin ini untuk memberikan kejelasan, konsistensi, dan dampak komunikasi yang maksimal. ${ }^{9}$ Menurut teori komunikasi pemasaran terpadu, untuk menghubungkan pelanggan atau calon pelanggan dengan suatu merek atau perusahaan, kegiatan kehumasan dibutuhkan sebagai jalur yang potensial untuk mempengaruhi atau memberi efek langsung kepada perilaku khalayak yang menjadi sasaran. Kegiatan kehumasan pula menjadi salah satu elemen penyusun komunikasi pemasaran terpadu yang penting digunakan untuk mencapai hasil maksimal dari sebuah kegiatan pemasaran. $^{10}$

\section{Bauran Pemasaran}

Penelitian ini didasarkan pada teori bauran promosi. Bauran promosi (promotion mix) merupakan paduan spesifik hubungan masyarakat, iklan, promosi penjualan, penjualan personal, dan sarana pemasaran langsung yang digunakan perusahaan untuk mengkomunikasi kan nilai pelanggan secara persuasif dan membangun hubungan pelanggan. ${ }^{11}$ Bauran promosi (promotion mix) suatu kesatuan dari berbagai strategi untuk mendapatkan target dari perusahaan poin-poin yang dimiliki

\footnotetext{
${ }^{10}$ https://ejournal.unsrat.ac.id/index.php/actadiurna/ article/view/15495/15036

${ }^{11}$ Philip Kotler, Gary Armstrong, Prinsip-Prinsip. Pemasaran. (Jakarta: Erlangga, 2006), 135
} 
oleh teori ini merupakan kombinasi yang tepat untuk pemasaran yang ditujukan kepada pelanggan. tentunya mereka tidak akan lepas dari proses untuk pencarian produk yang tepat harga yang tepat tempat yang tepat serta promosi yang tepat juga dimana promosi ini juga tidak serta merta pada satu channel saja terdapat iklan dan perjuangan personal yang tidak bisa lepas dari itu. bauran pemasaran sebagai serangkaian variabel pemasaran terkendali yang dipakai oleh perusahaan untuk menghasilkan tanggapan yang dikendalikan perusahaan dilakukan perusahaan untuk mempengaruhi permintaa nproduknya. Variabel-variabel yang dapat mempengaruhi pembeli adalah yang disebut 7P (Product, Price, Place, Promotion, Participant, Prosess, dan People Physical evidence). ${ }^{12}$ Untuk mencapai tujuan perusahaan dalam bidang pemasaran sesuai target yg telah ditentukan, pedoman yang mampu diandalkan pemimpin perusahaan itu penting. Oleh karena itu, strategi pemasaran yang menggunakan unsur variabel keempat tersebut sangat diperlukan dalam kegiatan pemasaran untuk dijadikan trigger

\section{Metodologi Penelitian}

Pendekatan penelitian ini menggunakan pendekatan pendekatan kualitatif bertujuan mencari informasi atau membangun satu makna atau menjelaskan makna dibalik realita. Peneliti berangkat dari peristiwa yang berlangsung di lapangan. Peneliti

12 Philip Kotler dan Kevin Lane Keller, Manajemen, 189. memilih menggunakan jenis penelitian kualitatif, karena penelitian lebih tepat digunakan untuk meneliti fenomena ini. Penelitian ini menggunakan metode penelitan kualitatif dengan tataran analisis deskriptif. Melalui penelitian analisis deskriptif peneliti merasa akan lebih mudah menjabarkan hasil dari data data dan fakta yang telah didapati di lapangan selama penelitian berlangsung.

Analisis data kualitatif ini dapat dilakukan dengan beberapa cara cara yang strukturnya adalah menggunakan data mengorganisasi data kemudian memilah-milah datanya menjadi satu kesatuan yang nantinya dapat di maknai sebagai pemaknaan yang lebih general kemudian menemukan pola dan apa yang penting dan bisa dimaknai atau dipelajari dalam penelitiannya yang kemudian dapat dibagikan kepada khalayak ramai.

Dalam tahap ini kemudian peneliti menggabungkan semua data-data berupa wawancara pengamatan di lokasi penelitian serta dokumen dokumen pendukung yang nantinya bisa dijadikan satu kemudian dicari kesimpulan untuk dilanjutkan penelitiannya lebih mendalam.

\section{Hasil dan Pembahasan}

Data yang telah peneliti peroleh dari hasil wawancara informan serta proses pengamatan yang telah dilakukan informasi selama beberapa waktu kemarin, kemudian data disusun oleh 
peneliti dan dianalisis, metode yang peneliti gunakan ini adalah metode deskriptif dimana metode deskriptif ini adalah suatu metode yang mempelajari masalah dan tata cara berlaku dalam masyarakat serta situasi dan kondisi tertentu yang memiliki sebuah tujuan untuk menggambarkan fenomena secara sistematis pada bidang tertentu secara faktual dan cermat. Proses itu baik itu yang telah peneliti amati dari outlet langsung dari kantor pemasarannya dan saat di rumah produksi lasagna larise sekalipun peneliti mengamati dengan cermat segala proses dari usaha-usaha pemasaran brand produk ini.

Data diatas merupakan gambaran total penjualan produk Lasagna Larise selama beberpa bulan terkahir. Pada awal tahun ini terlihat menurun karea memang adanya pengurangan iklan di lini online yang dilakukan pihak setempat. Dan hal itu memang terlihat signifikan. Melalui data ini bisa terlihat jelas perkembangannya , namun selain faktor iklan ada juga faktor lain yan mendukungnya.. Selain itu dari apa yang telah peneliti lakukan berikut adalah hasil deskripsi dan penyajian data yang telah peneliti peroleh sebagai berikut. Kegiatan pemasaran dari brand lasagna larise ini nyatanya tidak lepas dari konsep-konsep bauran dalam marketing mix yaitu;

a. Produk

Produk adalah segala sesuatu yang dapat ditawarkan kepada pasar untuk mendapatkan perhatian, dimiliki, digunakan atau dikonsumsi, yang meliputi barang secara fisik, jasa, kepribadian, lokasi, organisasi dan gagasan atau buah fikiran. Strategi bab produk dapat menpengaruhi strategi pemasaran lainnya. Pembelian sebuah produk bukan hanya sekedar untuk memiliki produk tersebut, tetapi juga untuk memenuhi keinginan konsumen. Perihal produk lasagna larise ini mengemas produknya dalam ukuran $7 \times 7 \mathrm{~cm}$, hal ini dikarenakan untuk ukuran $7 \times 7$ dirasa cukup untuk satu kali makan. Kemudian mereka mengemas dalam ukuran family pack atau isi 4. Hal ini juga dimaksudkan supaya bisa disimpan jika tidak bisa menghabiskan karena untuk ukuran yang terlalu besar biasanya ada yang tidak langsung bisa menghabiskan maka mereka menggunakan ukuran yang kecil untuk dipasarkan supaya lebih pas untuk porsi 1 orang 1 kali makan. Mengenai packaging mereka juga menggunakan aspek yang di desain untuk Frozen di mana dilapisi dengan bahan laminasi sehingga packaging nya kuat ketika terkena air atau basah dari lasagna ketika keluar dari freezer. Hal ini lebih difungsikan untuk menyiasati pengiriman yang ke luar kota atau bagi para reseller yang menjual kembali produknya di mana mereka tentunya pasti akan menyimpan produknya di dalam freezer dan packaging nya tentu harus kuat dan sesuai.

Selain ukuran kecil mereka juga menyediakan ukuran yang besar yakni 20x20 cm. Untuk ukuran lasagna yang besar ini ni hanya diproduksi ketika ada pesanan khusus yang biasanya untuk acara-acara besar seperti hari raya atau pertemuan keluarga. Dan untuk yang 
baru juga diproduksi ukuran yang medium dimana ukurannya cukup besar bagi mereka yang menyukai lasagna atau mungkin bisa 1 mangkok berdua dengan ukuran $14 \times 10$. Namun untuk ukuran medium ini masih dalam tahap tes produksi dan belum dipasarkan secara meluas. Untuk produk Lasagna Larise ini sendiri dirasa sudah cukup memenuhi angsa produk di kalangannya, menurut Astrid yakni admin sales online lasagna larise para pembeli dari produk ini rata-rata memberi respon yang positif di mana mereka puas dengan apa yang mereka dapatkan dengan harga yang mereka bayar bahkan ada yang berpendapat bahwa produknya tidak kalah dengan merk ternama seperti layaknya lasagna ala pizza hut. Dan produk ini repeat ordernya tinggi yang membuktikan bahwa produk ini mampu diterima di pasaran.

b. Place

Place atau lokasi kerapkali diartikan sebagai tempat pelayanan. Lokasi pelayanan yang digunakan dalam memasok jasa atau produk kepada pelanggan yang dituju merupakan kunci dari keputusan. Keputusan mengenai lokasi pelayanan yang akan digunakan melibatkan pertimbangan bagaimana penyampaian jasa ataupun produk kepada pelanggan dan di mana itu akan berlangsung. Tempat juga penting sebagai lingkungan di mana dan bagaimana jasa akan diserahkan, sebagai bagian dari nilai dan manfaat dari jasa dan produk yang dipasarkan.

Dalam hal ini ada tiga jenis interaksi yang mempengaruhi lokasi, yaitu konsumen mendatangi pemberi jasa, pemberi jasa mendatangi konsumen, dan pemberi jasa dan konsumen tidak bertemu secara langsung. Dari segi lokasi lasagna larise ini memiliki outlet tetap yang berada di Pakuwon trade center atau Pakuwon mall di mana bagi para pembeli yang ingin menikmati secara langsung produk ini bisa datang ke lokasi outlet. Sementara bagi yang tidak sempat pergi ke outlet maka disediakan layanan via online. Sehingga untuk lokasi produk ini dirasa fleksibel karena mempunyai store offline dan online sehingga bisa memudahkan untuk para pembeli melakukan transaksi tanpa perlu bersusah payah datang ke outlet bisa dikirim produknya sesuai keinginan.

c. Price

Strategi penentuan harga (pricing) harus konsisten dengan strategi marketing secara keseluruhan. Penentuan harga harus dimulai dengan pertimbangan atas tujuan penentuan harga itu sendiri. tiga dasar penetapan harga yang biasanya digunakan dalam menentukan harga, yaitu;

1. Penetapan harga berdasarkan biaya (cost-based pricing), untuk penetapan harga rasanya hati ini sudah sesuai standar menurut biaya yang dikeluarkan dimana dalam penentuan harganya sudah dihitung 
termasuk dengan biaya promosi biaya pokok produksi biaya sewa outlet biaya marketing biaya kirim dan lain sebagainya sudah ditentukan sejak awal sehingga halhal yang tidak diinginkan tidak sampai terjadi. Namun untuk saat ini dirasa masih belum begitu nampak lah banyak karena untuk penyewaan outlet sendiri terhitung double jadi untuk keuangannya terus berputar. Untuk penyesuaian harga juga sudah dilakukan di penjualan outlet karena harga bahan baku yang naik maka untuk penjualan di outlet disesuaikan karena kebutuhan di outlet juga cukup banyak makan dengan beberapa pertimbangan akhirnya harga produk untuk yang ada di outlet dinaikkan sebesar Rp 5.000 untuk menutupi untuk bahan baku

2. Penetapan harga berdasarkan persaingan (competition based pricing), Harga-harga para pesaing akan mempengaruhi tingkat permintaan jasa yang ditawarkan, sehingga harga pesaing harus turut dipertimbangkan dalam proses penetapan harga.penetapan penetapan harga produk nya juga sudah menyesuaikan dengan kondisi pasar yang ada di mana dari lasagna larise ini ibu Maya telah mensurvei produk produk serupa yang ada di kawasan Surabaya selain membandingkan rasa produknya harga yang ada di pasaran harga produk yang saat ini sudah berada di mana-mana ini.
3. Penetapan harga berdasarkan permintaan (demand based), artinya semakin tinggi mutu atau kualitas produk yang ditawarkan biasanya harga yang dipatok juga pastinya akan semakin tinggi menyesuaikan dengan kondisi dari produk yang dimiliki, semakin tinggi permintaan harganya tentu juga akan menyesuaikan kondisi pasar. untuk penetapan harga yang berdasarkan permintaan ini juga sudah diterapkan oleh tim lasagna larise dimana penetapannya ada diplatform website di mana mereka menaikkan harga untuk 2 produk yang dirasa best seller karena permintaan yang banyak tentunya harga dinaikkan masih sebanding dengan rasa yang akan mereka dapatkan tentunya dan hal itu terbukti pada akhirnya produk beef original dan Mac $n$ cheese tetap laku keras di pasaran karena memang product variant ini memang rata-rata digemari oleh para pecintanya.

\section{d. Promotion}

Promosi merupakan salah satu bentuk komunikasi yang sering dipakai oleh pemasar. Sebagai salah satu elemen bauran promosi, promosi penjualan merupakan unsur penting dalam kegiatan promosi produk. promosi merupakan upaya pemasaran yang bersifat media dan non media untuk merangsang rasa ingin tahu dari para konsumen, dengan cara meningkatkan permintaan dari 
konsumen atau untuk memperbaiki kualitas produk

Didalam promosi sendiri ada Lima unsur yang membentuk komunikasi pemasaran, karena merupakan peralatan dari promosi yaitu periklanan (advertising), penjualan personal (personal selling), promosi penjualan (sales promotion), hubungan masyarakat (pubilic relations), dan pemasaran langsung(direct marketing).

Dalam hal jual beli sangatlah erat dengan yang namanya pemasaran, pemasaran merupakan suatu rangkaian yang berguna untuk menyebar dan mempublis informasi tentang produk-produk yang sedang dipasarkan. Promotion Mix atau yang biasa disebut dengan bauran pemasaran merupak sebuah konsep pemasaran yang dalam konsep ini menjelaskan sebuah cara atau strategi untuk sebuah pemasaran yang sangat lengkap dan kompleks. Dari sini dapat diketahui bahwa tim dari lasagna larise ini sendiri telah melakukan poin-poin yang sudah terdapat pada teori bauran komunikasi atau marketing mix. Mereka memanfaatkan komunikasi secara internal maupun eksternal dan menggunakan penjualan langsung media juga untuk meningkatkan penjualannya maka mereka sangat memanfaatkan semua itu dengan baik. Relasi dengan customer maupun reseller pun tetap terbangun dengan baik bahkan hingga kini terdapat beberapa agen yang masih aktif dalam melakukan pembelian dalam jumlah besar hal itu juga tidak terlepas dari proses komunikasi yang terjalin di dalamnya. Tentunya lasagna larise dan tim ini terus mengusahakan agar produknya tetap dikenang di hati para konsumennya ketika mereka yang belum mengetahui produk ini pun dipersilahkan untuk mencoba tester terlebih dahulu sehingga itu akan membuat calon pembelinya akan lebih yakin dengan produk yang ditawarkan dan mereka juga lebih tahu lebih tahu lebih dulu rasa dari produknya sebelum membeli lebih tepatnya ini dipergunakan di outlet. Hal ini dilakukan untuk membuat persepsi calon pembeli menjadi yakin sehingga yakin untuk melakukan pembelian hal ini juga dilakukan di bazar-bazar yang mereka ikuti selama ini hal itu dilakukan untuk para pembeli selain itu mereka juga menyediakan kartu nama serta brosur-brosur sehingga ketika ada pemesanan meskipun di luar kota tetap bisa menjangkau dan tidak kehilangan konsumen. Diluar itu mereka juga tetap terus berinovasi dan memberikan pelayanan terbaik sebisa mungkin, demi kepuasan pelanggan. Selain itu mereka juga menggunakan metode follow up untuk meningkatkan relasi dengan para pembeli atau para resellernya. Metode ini cukup ampuh bagi mereka yang telah melakukan pembelian satu kali maupun lebih, tentunya hal ini tidak hanya serta merta melakukan follow up dan basa-basi 
biasa, hal ini juga dibarengi dengan penawaran-penawaran atau soft selling yang mereka tawarkan baik itu harga yang lebih murah dengan pengambilan yang lebih banyak atau free ongkir yang tetap berlaku mereka mendapatkan bonus di pembelian kedua seperti itu adalah contoh dari proses follow up mereka. Bagi mereka yang pertama melakukan pembelian atau masih menjadi lead yang belum closing, ada pula format penawaran penawaran yang mereka tawarkan untuk menggairahkan para calon pembelinya dan juga mereka memberikan penekanan penekanan tertentu jika ada seseorang yang terlihat serius untuk melakukan pembelian misalnya jika transfer hari ini nanti akan mendapatkan free tester atau mendapatkan potongan harga hari itu dilakukan agar ada keterdesakan di kalangan pembeli. Yang seringkali menarik minat mereka adalah pengiriman yang cepat tentunya semua orang yang menginginkan pembelian yang cepat sampai, hal itu yang sering menjadi bahan utama atau senjata pamungkas untuk menaklukkan calon pembelinya. Melalui persuasi-persuasi yang diberikan oleh kepada para calon pembelinya hal ini memang cukup menguntungkan karena setelah adanya iklan pasti tombak ujungnya adalah di sales yang memberikan edukasi langsung kepada para pembeli dan melalui edukasi ini dapat dilihat bagaimana penjualannya meningkat atau tidak kendala apa yang terjadi itu bisa juga dilihat dari titik sales nya.
Untuk mereka yang sudah melakukan dua kali pembelian biasanya akan melakukan pembelian ketiga keempat dengan sendirinya tanpa perlu di follow up karena mereka sudah memiliki sebuah kepercayaan dan mengetahui kualitas dari produk yang ia pasarkan kemudian dia bisa dengan mudah mempromosikan produk tersebut kepada khalayak market-nya. Menurut data ada 4 agen yang aktif dan 4 orang reseller pasif yang memang sudah berlangganan pembelia1n dalam jumlah yang besar, namun karena status reseller biasanya perputaran mereka tidak secepat yang berstatus agen.

Bauran promosi (promotion mix) adalah kombinasi strategi yang paling baik dari unsur-unsur promosi yang digunakan untuk mencapai tujuan perusahaan. Unsur-unsur tersebut merupakan alat dari komunikator pemasaran dalam berkomunikasi dengan pelanggan , bauran pemasaran terdiri atas segala hal yang bisa dilakukan perusahaan untuk mempengaruhi permintaan produknya. Dari data yang didapat oleh peniliti, kini peneliti dapat menyimpulkan adanya korelasi antara fakta di lapangan dengan teori yang digunakan. Dimana unsur-unsur dalam bauran komunikasi ini dipergunakan dengan baik pada perusahaan ini. Selain itu pada bab teori pemasaran terpadu ada juga titik korelasi dimana advertising yang dipergunakan oleh Lasagna larise ini cukup bisa dilihat hasilnya dengan pemasaran yang sudah 
merambah ke berbagai kota ini tentunya. Kemudian pada bagian teori komunikasi persuasi juga bisa di simpulkan terkait, dikarenakan adanya proses komunikasi. Dari hasil temuan yang peneliti ditemukan datanya juga menunjukkan adanya korelasi dengan komunikasi persuasif dimana mereka menggunakan metode metode seperti metode partisipasi dengan cara mereka membuat sebuah grup reseller yang di mana mereka bisa sharing satu sama lainnya. Kemudian adanya penekanan untuk memicu kecemasan untuk para calon pembelinya agar mereka segera melakukan pembelian. Mereka juga menawarkan benefit benefit tertentu dalam paket-paket yang ditonjolkan untuk menguatkan sugesti atau anjuran membeli produk yang mereka jual yaitu Lasagna Larise. Dari beberapa point yang telah peneliti sebutkan peneliti dapat menyimpulkan bahwa hasil dari penelitian ini juga cukup berkorelasi dengan teori komunikasi persuasif tentunya.

\section{Kesimpulan}

Dan akhirnya dari penelitian yang telah dilakukan dan analisis yang telah dibahas seperti di atas maka dapat disimpulkan bahwa komunikasi pemasaran yang dilakukan oleh brand lasagna larise ini menggunakan komunikasi secara eksternal maupun internal, dan berkaitan dengan bauran komunikasi atau marketing mix. Komunikasi pemasaran yang terjalin baik dari produsen tin lasagna larise reseller serta para customer yang merupakan pelanggan dari produk ini komunikasi secara internal tetap terjaga demi menghindari kesalahpahaman dan juga untuk meningkatkan penjualan dari lasagna larise itu sendiri sementara komunikasi secara eksternal lebih difungsikan untuk menggaet para konsumen baru dan khalayak umum pemasaran secara eksternal ini dilakukan melalui beberapa media yang kebanyakan adalah media online untuk meningkatkan penjualan tentunya. Selain menggunakan media media tertentu pemasaran secara langsung atau juga dilakukan untuk mempersuasi persepsi konsumen sehingga mereka tidak ragu untuk melakukan pembelian terhadap produk lasagna larise ini.

Lasagna larise ini selain melakukan pemasaran dari internet mereka juga tetap melakukan pemasaran secara konvensional dari outlet yang dimiliki dan mereka mengembangkannya dengan sistem riseller. Dari segi produk dan harga lasagna larise ini cukup di terima di khalayak. Dengan teori yang peneliti gunakan yakni teori bauran pemasaran peneliti merasa konsep dari teori ini memang benar-benar relevan untuk membicarakan tentang pemasaran produk lasagna larise sebagian besar dari poin-poin atau unsur yang dimiliki oleh teori bauran pemasaran ini relevan dengan kondisi yang ada saat ini. Lasagna larise yang merupakan contoh nyata dari perwujudan teori bauran pemasaran yang dicetuskan oleh kotler ini. Dengan 4 unsur terpenting nya yaitu product, place, price, promotion semuanya saling berkesinambungan dan saling berkaitan satu sama lainnya sesuai dengan 
data yang telah peneliti paparkan di atas terutama yang sudah peneliti jabarkan di bab 4 dengan korelasi teori yang ada maka bisa diketahui bahwa lasagna larise memang penggambaran yang tepat.

\section{Daftar Pustaka}

Alma, Buchari dan Ratih Hurriyati, Manajemen Corporate Strategi Pemasaran Jasa Pendidikan. Bandung: Alfabeta, 2008,

Darun, Hidayat. Komunikasi Antarpribadi dan Medianya. Yogyakarta: Graha Ilmu, 2012.

Fandy, Tjiptono. Strategi Pemasaran. Yogyakarta: Andi Press, 2004.

Gitosudarmo, Indriyono. Manajemen Strategis. Yogyakarta: BPFEYogyakarta, 2001.

Hamidi. Metode Penelitian Kualitatif. Malang: Universitas Muhammadiyah. Malang, 2004.

Kotler, Philip \& Gary Armstrong. PrinsipPrinsip Pemasaran. Jakarta: Erlangga, 2006.

Kotler, Philip dan Kevin Lane Keller.

Manajemen Pemasaran, terj. Benyamin Molan, ed. 13. Jakarta: PT. Indeks, 2009.

Lupiyoadi, Rambat dan A. Hamdani. Manajemen Pemasaran Jasa. Jakarta: Salemba Empat, 2009.

Moleong, Lexy. J. Metodologi Penelitian Kualitatif. Bandung: Remaja Rosdakarya, 2009.

Mudjiono, Yoyon. Ilmu Komunikasi. Surabaya: Jaudar Press, 2012.
Prayudi. Public Relations Stratejik. Yogyakarta: Komunikasi UPN Press, 2012.

Sofjan, Assauri. Manajemen Pemasaran Dasar, Konsep dan Strategi. Jakarta: PT. Raja Grafindo Persada, 2007.

Sutisna. Perilaku Konsumen dan Komunikasi Pemasaran. Bandung: PT. Remaja Rosdakarya, 2003.

Swasta dan Irawan. Manajemen Pemasaran Modern. Yogyakarta: Liberty, 2003. 